\title{
Correction to: Small area estimation of proportions under area-level compositional mixed models
}

\author{
María Dolores Esteban ${ }^{1}$ - María José Lombardía ${ }^{2}$ Esther López-Vizcaíno ${ }^{3}$. \\ Domingo Morales ${ }^{1} \cdot$ Agustín Pérez $^{1}$ (D)
}

Published online: 29 March 2021

(c) Authors 20212021

\section{Correction to: TEST \\ https://doi.org/10.1007/s11749-019-00688-w}

The article Small area estimation of proportions under area-level compositional mixed models, written by María Dolores Esteban, María José Lombardía, Esther López-Vizcaíno, Domingo Morales \& Agustín Pérez, was originally published Online First without Open Access. After publication in volume 29, issue 3, page 793-818, the author decided to opt for Open Choice and to make the article an Open Access publication. Therefore, the copyright of the article has been changed to (C) Authors 2021 and the article is forthwith distributed under the terms of the Creative Commons Attribution.

Open Access This article is licensed under a Creative Commons Attribution 4.0 International License, which permits use, sharing, adaptation, distribution and reproduction in any medium or format, as long as you give appropriate credit to the original author(s) and the source, provide a link to the Creative Commons licence, and indicate if changes were made.

The images or other third party material in this article are included in the article's Creative Commons licence, unless indicated otherwise in a credit line to the material. If material is not included in the article's Creative Commons licence and your intended use is not permitted by statutory regulation or exceeds the permitted use, you will need to obtain permission directly from the copyright holder.

To view a copy of this licence, visit http://creativecommons.org/licenses/by/4.0/

The original article can be found online at https://doi.org/10.1007/s11749-019-00688-w.

Agustín Pérez

agustin.perez@umh.es

1 Universidad Miguel Hernández de Elche, Alicante, Spain

2 CITIC, Universidade da Coruña, A Coruña, Spain

3 Instituto Galego de Estatística, Santiago de Compostela, Spain 
Publisher's Note Springer Nature remains neutral with regard to jurisdictional claims in published maps and institutional affiliations. 